

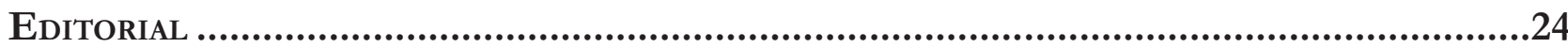

O Direito na fronteira da razão: Psicologia, neurociência e economia comportamental................... 24 Patrícia Perrone Campos Mello e Sergio Nojiri

I. NeURodireito: COGNIÇão, EMOÇÃo, JUÍZOS MORAIS E CIÊNCIA ..........................................26

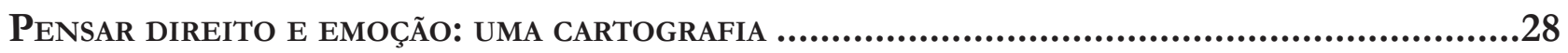

Nevita Maria Pessoa de Aquino Franca Luna

Neurodireito: o início, o fim E O MEIO

Carlos Marden e Leonardo Martins Wykrota

ENSAIO JURÍDICO SOBRE A RACIONALIDADE HUMANA: MAIORES, CAPAZES E IRRACIONAIS

André Perin Schmidt Neto e Eugênio Facchini Neto

DIVERGÊNCIAS DE PRINCÍPIO: ARGUMENTOS JURÍDICOS E MORAIS EM UM CENÁRIO DE DESACORDOS SOCIAIS

André Matos de Almeida Oliveira, Pâmela de Rezende Côrtes e Leonardo Martins Wykrota

CONSILIÊNCIA E A POSSIBILIDADE DO NEURODIREITO: DA DESCONFIANÇA À RECONCILIAÇÃO DISCIPLINAR.....

Thaís de Bessa Gontijo de Oliveira e Renato César Cardoso

MODELOS DE MORALIDADE

Molly J. Crockett

A INFELIZ BUSCA POR FELICIDADE No DiREITo

Úrsula Simões da Costa Cunha Vasconcellost, Noel Struchiner e Ivar Hannikainen

Além da liberdade: PersPeCtivas Em Nietzsche.

Lucas Costa de Oliveira

A mediaÇão de CONFlitos SOb a PERSPECTIVA do DESENVOLVIMENTO HUMANO: AS CONTRIBUIÇÕES DA PSICOLOGIA POSITIVA

Simone de Biazzi Ávila Batista da Silveira e Deise Brião Ferraz

Neuroimagiologia e aValiação de ResPonsabilidade

Nicole A. Vincent 
ANÁLISE CRÍTICA DA ORIENTAÇÃO DE CIDADÃOS COMO MÉTODO PARA OTIMIZAR DECISÕES PÚBLICAS POR MEIO DA TÉCNICA NUDGE.

Luciana Cristina Souza, Karen Tobias França Ramos e Sônia Carolina Romão Viana Perdigão

Políticas públicas e o deVer de monitoramento: “LEVANdo os Direitos A SÉrio". .252 Ana Paula de Barcellos

Nudges E POLÍticas PÚblicas: uM MECANISMO DE COMBATE AO TRABALHO EM CONDIÇÃo ANÁLOGA À DE ESCRAVO .267

Amanda Carolina Souza Silva, Débhora Renata Nunes Rodrigues e Saul Duarte Tibaldi

REDUZINDO A TRIBUTAÇÃO COGNITIVA: LIÇÕES COMPORTAMENTAIS PARA A DIMINUIÇÃO DOS EFEITOS PSICOLÓGICOS ADVERSOS DA POBREZA.............................................................288 Leandro Novais e Silva, Luiz Felipe Drummond Teixeira, Gabriel Salgueiro Soares e Otávio Augusto Andrade Santos

Políticas PÚBLICAS EM SUICÍDIO: DO PATERNALISMO CLÁSSICO AO PATERNALISMO LIBERTÁRIO E NUDGING

Davi de Paiva Costa Tangerino, Gabriel Cabral e Henrique Olive

Nudges COMO POLÍticA PÚbliCA PARA AUMENTAR O ESCASSO NÚMERO DE DOADORES DE ÓRGÃos PARA TRANSPLANTE

Roberta Marina Cioatto e Adriana de Alencar Gomes Pinheiro

Os PROGRAMAS DE INTEGRIDADE PARA CONTRATAÇÃO COM A ADMINISTRAÇÃO PÚBLICA ESTADUAL: NUDGE OU OBRIGAÇÃo LEGAL? UM OLHAR SOBRE AS DUAS PERSPECTIVAS .386

Cíntia Muniz Rebouças de Alencar Araripe e Raquel Cavalcanti Ramos Machado

Paternalismo libertário e Proteção JURídica do AMbiente: POR QUe PROTEger o AMBIENTE TAMBÉM DEVE SER PROTEGER AS LIBERDADES?

Mariana Carvalho Victor Coelho e Patryck de Araujo Ayala

Políticas PÚblicas baseadas EM EVIdÊNCIAS COMPORTAMENTAIS: REFLEXões A PARTIR do Projeto de Lei 488/2017 do Senado

Pâmela de Rezende Côrtes, André Matos de Almeida Oliveira e Fabiano Teodoro de Rezende Lara

III. ECONOMIA COMPORTAMENTAL: VIESES COGNITIVOS E POLÍTICAS PÚBLICAS .455

ECONOMIA COMPORTAMENTAL E DIREITO: A RACIONALIDADE EM MUDANÇA Marcia Carla Pereira Ribeiro e Victor Hugo Domingues

VIESES COGNITIVOS E DESENHO DE POLÍTICAS PÚBLICAS 
A neurociênCia da moralidade na tomada de DeCisões Jurídicas Complexas e No DESENHO DE POLÍTICAS PÚBLICAS

Erik Navarro Wolkart

Desvio de CARÁter ou SIMPLESMENTE HUMANO? ECONOMIA COMPORTAMENTAL APLICADA AO COMPORTAMENTO DESONESTO

Diana Orghian, Gabriel Cabral, André Pinto e Alessandra Fontana

Políticas Públicas e a ConcretizaÇão de direitos sociais: TOMAdA DE DECisão, ARQUITETURA DE ESCOLHAS E EFETIVIDADE

Ana Elizabeth Neirão Reymão e Ricardo dos Santos Caçapietra

BEHAVIORAL ECONOMICS E DIREITO DO CONSUMIDOR: NOVAS PERSPECTIVAS PARA O ENFRENTAMENTO DO SUPERENDIVIDAMENTO .568

Samir Alves Daura

A EDUCAÇÃo FORMAL PARA O CONSUMO É GARANTIA PARA UMA PRESENÇA REFLETIDA DO CONSUMIDOR NO MERCADO? UMA ANÁLISE COM BASE NA BEHAVIORAL LAW AND ECONOMICS (ECONOMIA COMPORTAMENTAL) 600

Marcia Carla Pereira Ribeiro e Edson Mitsuo Tiujo

LIBET, DETERMINISMO E CONSUMO: AS INFLUÊNCIAS DO MARKETING E A RELEVÂNCIA DA DELIBERAÇÃo CONSCIENTE NA SUPERAÇÃo CONDICIONAL DE HÁBITOS DE CONSUMO PERIGOSOS616 Émilien Vilas Boas Reis e Leonardo Cordeiro de Gusmão

CiÊNCIA DO DIREITO TRIBUTÁRIO, ECONOMIA COMPORTAMENTAL E EXTRAFISCALIDADE. .640 Hugo de Brito Machado Segundo

IV. CoMportamento JUdiCiAL: INFLUÊNCIA DE FATORES EXTRAJURÍDicos .660

FATORES METAPROCESSUAIS E SUAS INFLUÊNCIAS PARA A FORMAÇÃo DA DECISÃo JUDICIAL .662 Rogério Roberto Gonçalves de Abreu, Lúcio Grassi de Gouveia e Virgínia Colares

“A VIDA COMO ELA É": COMPORTAMENTO ESTRATÉGICO NAS CORTES Patrícia Perrone Campos Mello

A COMPOSIÇÃo do ÓRGão COLEGIAdo E SEUS EFEITOS NA TOMADA DE DECISÃo .720 André Garcia Leão Reis Valadares

Das 11 ilhas ao centro do arquipélago: os superpoderes do Presidente do STF DURANTE O RECESSO JUDICIAL E FÉRIAS .741 José Mário Wanderley Gomes Neto e Flávia Danielle Santiago Lima 
RAZÃo, EMOÇÃo E DELIBERAÇÃO: AS ADEQUAÇÕES REgIMENTAIS do SUPERIOR TribUNAL DE JUSTIÇA PARA A FORMAÇÃo DE PRECEDENTES EFICAZES

Peter Panutto e Lana Olivi Chaim

Heurística de ancoragem e fiXaÇÃo de danos morais em JUizados especiais Cíveis no Rio DE JANEIRO: UMA NOVA ANÁLISE 778

Fernando Leal e Leandro Molhano Ribeiro

LA PROTECCIÓN DE LOS DERECHOS POLÍTICOS FRENTE A LAS FUNCIONES DISCIPLINARIAS DE LAS AUTORIDADES ADMINISTRATIVAS: SUBSIDIARIEDAD Y DEFERENCIA EN EL SISTEMA INTERAMERICANO DE DERECHOS HUMANOS Jorge Ernesto Roa Roa

V. A influênCia do gÊNERo no PROCESSO DECisório JUdiCial

Como os Juízes decidem os Casos de estupro? ANALISANDo SENTENÇAS SOb A PERSPECTIVA DE VIESES E ESTEREÓTIPOS DE GÊNERO 826 Gabriela Perissinotto de Almeida e Sérgio Nojiri

GÊNERO E COMPORTAMENTO JUDICIAL NO SUPREMO TRIBUNAL FEDERAL: OS MINISTROS CONFIAM MENOS EM RELATORAS MULHERES?

Juliana Cesario Alvim Gomes, Rafaela Nogueira e Diego Werneck Arguelhes

Hércules, Hermes e a Pequena Sereia: uma reflexão sobre estereótipos de gênero, SUBPRESENTAÇÃo DAS MULHERES NOS TRIBUNAIS E (I)LEGITIMIDADE DEMOCRÁTICA DO PODER JUDICIÁRIO. .878 Jane Reis Gonçalves Pereira e Renan Medeiros de Oliveira

Prisão Cautelar de gestantes: análise do Fundamento filosófico da decisão do Habeas CoRpus N. 143.641 912

Artur César Souza e Giovania Tatibana de Souza

VI. Neurodireito APlicado ao direito E Ao Processo PENAL....................................926

CÉREbros QUe PUNEM: UMA REVISÃo CRÍTICA DA NEURoCIÊNCIA DA PUNIÇÃo .....................928 Ricardo de Lins e Horta

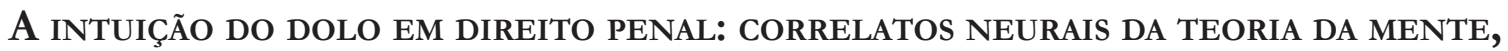
RACIOCÍNIO INDUTIVO E A GARANTIA DA CONVICÇÃO JUSTIFICADA. .946 Thiago Dias de Matos Diniz e Renato César Cardoso

As COMUNIDADES EPISTÊMICAS PENAIS E A PRODUÇÃo LEGISLATIVA EM MATÉRIA CRIMINAL..... 961 Stéphane Enguéléguélé 
DELINQUÊNCIA JUVENIL: RELAÇÕES ENTRE DESENVOLVIMENTO, FUNÇÕES EXECUTIVAS E COMPORTAMENTO SOCIAL NA ADOLESCÊNCIA .

André Vilela Komatsu, Rafaelle CS Costa e Marina Rezende Bazon

Límites TEMPORALES A LAS PENAS PRIVATIVAS DE LIBERTAD ATENDIENDO AL DESARROLLO PSICOSOCIAL.

Silvio Cuneo Nash

NEURolaw E AS PERSPECTIVAS PARA UMA ANÁLISE OBJETIVA DO COMPORTAMENTO SUGESTIONADO: REPERCUSSÃO DAS FALSAS MEMÓRIAS NA ESFERA PENAL

Mariana Dionísio de Andrade, Marina Andrade Cartaxo e Rafael Gonçalves Mota

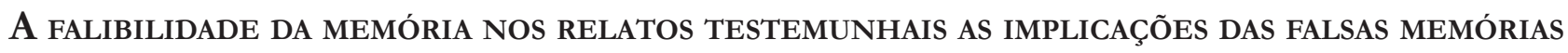
NO CONTEXTO DOS CRIMES CONTRA A DIGNIDADE SEXUAL

Caroline Navas Viana

A (IR)REPETIBILIDADE dA PROVA PENAL DEPENDENTE DA MEMÓRIA: UMA DisCUSSÃo COM BASE NA PSICOLOGIA DO TESTEMUNHO. 1058

William Weber Cecconello, Gustavo Noronha de Avila e Lilian Milnitsky Stein 


\section{A educação formal para o consumo é garantia para uma presença refletida do consumidor no mercado? Uma análise com base na behavioral law and economics (economia comportamental)*}

\author{
Is the formal education for consumption a \\ guarantee for a reflected presence of the \\ consumer in the market? An analysis from \\ behavioral law and economics
}

\author{
Marcia Carla Pereira Ribeiro** \\ Edson Mitsuo Tiujo***
}

\section{Resumo}

O Código do Consumidor, para além do direito à informação (art. $6^{\circ}$, III), previu o direito básico à educação (art. $6^{\circ}$, II), como forma de assegurar a liberdade de escolha e a igualdade nas contratações. O artigo analisa esse direito básico pela metodologia da Análise Econômica do Direito, notadamente, pela vertente da economia comportamental. Verifica se a educação formal tem o condão de influir na alteração de comportamento do consumidor, proporcionando-lhe um maior poder de reflexão. Partindo-se do pressuposto de que a melhor forma de aprendizagem do consumidor é pelos erros cometidos no passado (experiência) e que as distorções cognitivas (heurísticas e vieses) são invencíveis, mesmo diante de ostensiva informação e educação, os behavioristas parecem não crer na educação formal, como o meio primordial para amenizar a limitação da racionalidade.

Palavras-chave: Direito à educação. Direito do consumidor. Economia comportamental. Heurísticas e vieses.

\begin{abstract}
The Consumer Code, in addition to the right to information (art. $6^{\circ}$, III), established the basic right to education (art. $6^{\circ}$, II), as a way of ensuring the liberty of choice and equality in contracting. The article analyzes this basic right by the methodology of the economic analysis of the law, especially by the behavioral economy. It verifies whether formal education has any influence on the consumer behavior change, providing a greater power of reflection. Based on the assumption that the best way of learning, for the consumer, is by the mistakes he made on the past (experience) and that the cognitive distortions (heuristics and biases) are invincible, even when facing
\end{abstract}


the ostensive information and education, the behaviorists seems not to believe in formal education as a crucial means to soften the limitation of rationality.

Keywords: Right to education. Consumer law. Behavioral economics. Heuristics and biases.

\section{INTRODUÇÃo}

O artigo busca correlacionar normas do Direito do Consumidor à luz de uma inovadora abordagem do Direito, a Análise Econômica do Direito ou law and economics. Com base na economia comportamental ou behavioral law and economics, foram consideradas a coerência e a plausibilidade de algumas das regras básicas do Direito do Consumidor.

O estudo traz uma aproximação do direito básico à educação formal do consumidor com os insights da economia comportamental, notadamente, com o intuito de apresentar, de uma maneira bastante inicial, a coerência (ou não) dessa moderna metodologia de estudo.

A proposta de estudo partiu de alguns questionamentos prévios em relação ao consumidor relacionadas à sua vulnerabilidade; às práticas comerciais dos fornecedores como fator de influência no comportamento consumista dos consumidores; e, especialmente, sobre a potencialidade de a educação formal possibilitar maior poder de reflexão aos consumidores, especialmente quando delegado aos fornecedores o dever de prestá-la.

O primeiro desses questionamentos está superado e pacificado, qual seja, os consumidores realmente se encontram em posição de inferioridade frente aos fornecedores. Sobre ele, estão de acordo, tanto juristas como economistas e psicólogos. É preciso, agora, verificar se a educação formal para o consumo (direito básico do consumidor) é primordial e essencial para eliminação ou exclusão dessa situação do consumidor, permitindo-lhe uma atuação mais refletida no mercado.

Para tanto, o presente artigo é dividido em quatro partes, sendo a primeira destinada à exposição do conteúdo do direito à educação para o consumo. Nesse tópico, são expostos os fundamentos legais e doutrinários acerca do direito à educação, distinguindo-o do direito à informação e, ao fim, expondo-se as práticas comerciais e as políticas econômicas, notadamente aquelas indutoras do consumismo, às quais os consumidores estão constantemente submetidos.

A segunda e a terceira partes incursionam o leitor pela metodologia da Análise Econômica do Direito, especificamente na linha da economia comportamental. O terceiro tópico é destinado à exposição e à exemplificação de algumas heurísticas e vieses (manifestações neurocognitivas) que podem alterar os comportamentos dos consumidores, conduzindo-os a erros sistemáticos.

Por último, o quarto tópico destina-se à correlação das duas variáveis objeto de estudo, quais sejam, a educação formal e inicial para o consumo à luz da economia comportamental. Procura-se verificar se a educação de crianças e jovens, como política pública, tende a alterar o comportamento do consumidor no mercado de consumo, permitindo-lhes um maior poder de reflexão.

\section{O diREITO BÁsico À EdUCAÇão PARA O CONSUMO COMO GARANTIA DE PROTEÇÃo aO CONSUMIDOR, DIANTE DAS PRÁTICAS COMERCIAIS E DAS POLÍTICAS ECONÔMICAS INDUTORAS DO CONSUMO}

A Constituição da República de 1988 assegurou ampla proteção ao consumidor, alçando a sua tutela a direito fundamental (art. 5', XXXII), bem como Princípio da Ordem Econômica (art. 170, V). Nesse 
enfoque, estabeleceu, ainda, que a defesa do consumidor deve ser realizada ao lado de outros importantes princípios como os da propriedade, da livre iniciativa e da livre concorrência, aparentemente contraditórios, mas em verdades correspondentes.

Para a concretização dessa proteção, o Poder Constituinte ordenou ao legislador ordinário, por meio do art. 48 do Ato das Disposições Constitucionais Transitórias, a elaboração de uma lei de defesa do consumidor, a qual foi aprovada e entrou em vigência em 1990, sendo conhecida como Código de Defesa do Consumidor (Lei n. 8.078).

O Código de Defesa do Consumidor, por sua vez, garantiu como direito básico do consumidor o direito à informação (art. $6^{\circ}, \mathrm{III}$ ), mas não apenas isso, previu, ainda, o direito à educação do consumidor como forma de assegurar a liberdade de escolha e a igualdade nas contratações (art. $6^{\circ}$, II).

O direito básico à informação é exaustivamente difundido pela doutrina, aplicado pela jurisprudência e seguido pelos fornecedores, na medida dos seus custos e estratégias comerciais. O direito à informação consiste em transmitir ao consumidor informações sobre o produto e/ou serviço comercializado, notadamente, no que se refere a suas características, quantidade, qualidades, composição, preço, garantia, prazos de validade, origem e os riscos que apresentam à saúde e à segurança dos consumidores (art. 30 do Código do Consumidor).

O direito à informação decorre dos princípios da transparência e da vulnerabilidade do consumidor (art. $4^{\circ}$, I do Código do Consumidor). Esse postulado pode ser relacionado a um elemento da Análise Econômica do Direito, a assimetria informacional.

Nos estudos de Maria Paula Costa Bertran Muñoz ${ }^{1}$, a vulnerabilidade do consumidor é o reflexo jurídico da assimetria de informações. Isso significa que os agentes possuem uma racionalidade que é limitada pela incompletude do conhecimento, bem como das competências cognitivas de receber, armazenar, recuperar e processar as informações ${ }^{2}$. Em simples palavras, reconhecer a assimetria de informações em determinados mercados específicos é reconhecer o fato de que uma das partes sabe muito mais sobre as reais qualidades do que está negociando do que a outra ${ }^{3}$, acarretando situações indesejadas (falhas de mercado) e obstaculizando relações econômicas mais eficientes ${ }^{4}$.

O exemplo típico de uma situação informacional assimétrica, citado por Arkelof, é o mercado de veículos usados. É inegável que os vendedores têm maior conhecimento sobre a qualidade do carro do que os compradores. No entanto, no mercado, bons veículos e maus veículos têm o mesmo preço, de modo que é impossível para o comprador observar essa diferença no momento da negociação ${ }^{5}$.

Ademais, embora pareça bastante, a proteção ao consumidor não se limita à sua adequada $\left(\operatorname{art} .6^{\circ}\right.$, III do Código do Consumidor), necessária (art. $8^{\circ}$ ) e ostensiva (art. $9^{\circ}$ ) informação. Vai além. O Código do Consumidor assegurou, ainda, como direito básico do consumidor, o direito à sua educação.

O direito à educação, portanto, é um direito distinto do direito à informação. O direito à educação consiste no direito do consumidor em ser dotado de poder de reflexão e de conscientização acerca do consumo de bens e serviços (art. $6^{\circ}$, II do Código do Consumidor), minimizando, assim, a sua irracionalidade, a sua

1 MUÑOZ, Maria Paula Costa Bertran. Paralelismo entre assimetria de informações e vulnerabilidade dos consumidores: uma análise acerca de juros em contratos de concessão de crédito. Revista de Direito do Consumidor, São Paulo, v. 86, p. 47-63, mar./abr. 2013. p. 52.

2 WILLIAMSON, Oliver. The mecanisms of governance. New York: Oxford University Press, 1996. p. 377.

3 MUÑOZ, Maria Paula Costa Bertran. Paralelismo entre assimetria de informações e vulnerabilidade dos consumidores: uma análise acerca de juros em contratos de concessão de crédito. Revista de Direito do Consumidor, São Paulo, v. 86, p. 47-63, mar./abr. 2013. p. 52.

4 RIBEIRO, Marcia Carla Pereira; GALESKI JUNIOR, Irineu. Teoria geral dos contratos: contratos empresariais e análise econômica. 2. ed. São Paulo: Revista dos Tribunais, 2015. p. 110-111.

5 RIBEIRO, Marcia Carla Pereira; GALESKI JUNIOR, Irineu. Teoria geral dos contratos: contratos empresariais e análise econômica. 2. ed. São Paulo: Revista dos Tribunais, 2015. p. 110-111. 
limitação decorrente da assimetria de informações, notadamente frente ao fornecedor, e o desequilíbrio da relação de consumo em virtude do poder econômico do fornecedor.

A racionalidade limitada, a assimetria de informações e o poder econômico são postulados da Análise Econômica do Direito e tidos como falhas de mercado. A presença dessas falhas de mercado, notadamente nas relações de consumo, impedem que as relações econômicas possam alcançar a plena eficiência apenas pela transação entre os agentes, cabendo às regras jurídicas, quando possível, dirimir tais falhas ${ }^{6}$.

Nesse aspecto, tanto consumeristas quanto economistas, notadamente os comportamentalistas, estão de acordo a respeito de a propensão da relação jurídica consumerista sofrer os efeitos das falhas de mercado, podendo-se imaginar que a alteração dessa realidade se processe por meio da educação para o consumo.

A Associação de Educação Financeira do Brasil (AEFB) propõe que os consumidores aprendam a controlar seus recursos e respeitar seu orçamento, administrar seus bens e alocar seus recursos e, primordialmente, quer estimular a promoção de uma mudança de comportamento e de velhos hábitos com relação ao uso do dinheiro. Em outras palavras, seu escopo consiste em desenvolver nos jovens as competências e habilidades necessárias para lidar com as decisões financeiras que tomarão ao longo de suas vidas?

Afora iniciativas dessa ordem, ao que se nota, os objetivos propostos pelos idealizadores ${ }^{8}{ }^{9}$ da educação para o consumo são: (a) incutir no consumidor o poder de reflexão e o juízo crítico, especialmente diante das políticas econômicas de incentivo ao consumo e as práticas comerciais (oferta e publicidade) dos fornecedores; (b) proteger o consumidor, especialmente as crianças, pré-adolescentes e adolescentes diante das práticas comerciais (oferta e publicidade) dos fornecedores; (c) promover a sustentabilidade e o consumo consciente, com vistas à proteção do meio ambiente para as gerações futuras; e, sobretudo, (d) incutir no espírito de cada consumidor uma nova mentalidade, mais exigente e aguerrida, especialmente, quanto à postulação dos seus direitos, tornando-o um cidadão mais forte, ciente de seus direitos e com a verdadeira vontade de brigar por eles.

O direito à educação, por outro lado, não se refere à transmissão de conhecimentos financeiros ou econômicos, como noções sobre juros ou capitalização de juros, encargos embutidos e aquisições em longo prazo. Tampouco consiste em um conjunto de ferramentas de cálculos matemáticos. Notadamente, tais conhecimentos, ainda que relevantes, não têm o condão de alterar, substancialmente, o comportamento do consumidor, já que não age em seu consciente refletido, como será mais bem exposto nos tópicos abaixo.

$\mathrm{Na}$ lição de Sergio Cavalieri Filho ${ }^{10}$, a educação para o consumo envolve dois aspectos: o formal e o informal. O primeiro, desenvolve-se por meio de políticas de inserção de temas relacionados ao direito do consumo e consumidor nos currículos escolares, desde o ensino fundamental, em escolas públicas e privadas, até o ensino universitário, em disciplina com autonomia científica e pedagógica, constituindo importante ferramenta para a construção da cidadania e para a formação de indivíduos conscientes. O segundo desenvolve-se por meio das mídias de comunicação social e/ou institucional, direcionadas a um público geral ou específico, com o intuito de prestar informações, orientações e/ou esclarecimentos aos consumidores.

Ezequiel Morais et alii ${ }^{11}$, em acréscimo, ensina que a educação se volta para dois planos: o inicial e a con-

6 RIBEIRO, Marcia Carla Pereira; GALESKI JUNIOR, Irineu. Teoria geral dos contratos: contratos empresariais e análise econômica. 2. ed. São Paulo: Revista dos Tribunais, 2015. p. 107-108.

7 ASSOCIAÇÃO DE EDUCAÇÃO FINANCEIRA DO BRASIL. Educação financeira nas Escolas. Disponível em: < http://www. aefbrasil.org.br/index.php/programas-e-projetos/educacao-financeira-nas-escolas/>. Acesso em: 6 fev. 2018.

8 CAVAliERI FILHO, Sergio. Programa de direito do consumidor. 4. ed. São Paulo: Atlas, 2014. p. 101-102.

9 EFING, Antônio Carlos; POLEWKA, Gabriele; OYAGUE, Olenka Woolcott. A crise econômica brasileira e o superendividamento da população: emergência do aprimoramento legislativo para a tutela social. Revista de Direito do Consumidor, São Paulo, v. 24, n. 101, set./out. 2015. p. 327.

10 CAVALIERI FILHO, Sergio. Programa de direito do consumidor. 4. ed. São Paulo: Atlas, 2014. p. 101-102.

11 MORAIS, Ezequiel; PODESTÁ, Fábio Henrique; CARAZAI, Marcos Marins. Código de Defesa do Consumidor comentado. São Paulo: Revista dos Tribunais, 2010. p. 93. 
tínua (ou permanente). O primeiro é aquele inserido no currículo escolar, nos anos iniciais da vida escolar, preparando o cidadão para a construção de um projeto de vida. O segundo é aquele ofertado, continuamente, no mercado de consumo, com o objetivo de proporcionar o conhecimento mínimo de dados referentes à qualidade dos produtos e serviços, nos seus aspectos de saúde, segurança, informação, associativismo e para o próprio consumo.

Diante dessas proposições, denota-se que o direito à educação para o consumo deve fazer parte de toda a vida do cidadão, estando presente na sua vida escolar e orientando-o no mercado de consumo, sendo tal encargo de responsabilidade, principalmente, da própria família, ainda que modo informal, do Estado e, pontual e excepcionalmente, do fornecedor. Nesse particular, não se corrobora o entendimento de que o fornecedor deva promover a educação do consumidor, não por causa do conflito de interesses, mas sim porque, na mentalidade dos economistas, isso geraria maiores custos de transação ${ }^{12}$, acarretando a transferência desses custos para o próprio mercado de consumo.

O assunto ora discutido e estudado torna-se ainda mais relevante quando se percebe a apelação das práticas comerciais do mercado de consumo e também a política econômica adotada pelo país. É evidente que o empresário que atua no mercado com o objetivo exclusivo de lucro deverá envidar todos os seus esforços para a comercialização de seus produtos e serviços, disponibilizando, para tanto, ofertas e publicidades direcionadas a angariar clientes consumidores. Da mesma forma, o Estado brasileiro que é, por opção, capitalista, tende à adoção de políticas econômicas voltadas ao crescimento e desenvolvimento econômicos. É certo, contudo, que esse mesmo Estado não pode se dissociar do bem-estar social, o que não é contraditório, mas perfeitamente conciliável ${ }^{13}$. Inclusive, a Constituição da República, em seu art. 170 e incisos, dispôs como Princípios da Ordem Econômica, a livre iniciativa, a propriedade privada e a livre concorrência ao lado da defesa do consumidor.

O fornecedor (empresário) afeta a racionalidade do consumidor, buscando distorcer a sua liberdade de atuação e escolha, por uma série de fatores, como (a) as práticas comerciais de oferta e publicidade, constantemente renovadas por técnicas cada vez mais bem elaboradas e, muitas delas, agressivas ${ }^{14}$ e super-estimuladoras do consumo. Por essa razão, chamadas de "armas de sedução do fornecedor" ${ }^{15}$ com o intuito de influenciar o público em geral; (b) o desenvolvimento tecnológico dos computadores e telefones móveis, aliado à melhoria da qualidade dos sinais de internet e a facilitação do acesso do público em geral a esses produtos (computadores e celulares) e serviços (internet); (c) a facilitação na concessão / aquisição de créditos pelos consumidores, "sobretudo a concessão do "dinheiro de plástico" (cartões de crédito) e cheques especiais" "16 além do crédito consignado em benefício previdenciário e salário e os créditos on line; e (d) o não cumprimento a contento pelos fornecedores (empresários) das regras básicas de proteção ao consumidor, especialmente, no que se refere à oferta de preços, regulada pelo Decreto n. 5.903/2006, a qual impõe uma série de regras que não são aplicadas no dia a dia do mercado de consumo ${ }^{17}$.

Como consequência de tais práticas comerciais, os consumidores mais açodados e consumistas têm sido levados a uma situação de desespero diante do consumo exagerado ${ }^{18}$, os consumidores menos reflexivos têm sido vítimas frequentes de armadilhas promocionais do tipo "pague 2 e leve 3" e "prestações sem ju-

12 Custos de transação são os custos das partes para realizar negociações e para fazer cumprir as obrigações.

13 COURI, Sergio. Liberalismo e societalismo. Brasília: UnB, 2001. p. 5 e seguintes.

14 MARQUES, Cláudia Lima. Manual de direito do consumidor. 6. ed. São Paulo: Revista dos Tribunais, 2014. p. 75.

15 TARTUCE, Flavio; NEVES, Daniel Amorim Assumpção. Manual de direito do consumidor: direito material e processual. 2 . ed.

São Paulo: Método, 2013. p. 326.

16 FILOMENO, José Geraldo Brito. Manual de direitos do consumidor. 13. ed. São Paulo: Atlas, 2015. p. 127.

17 Por exemplo, o art. $3^{\circ}$ do referido Decreto estabelece que, na concessão de crédito, o fornecedor deverá informar de maneira discriminada, o valor total a ser pago com financiamento; o número, periodicidade e valor das prestações; os juros; e, os eventuais acréscimos e encargos que incidirem sobre o valor do financiamento ou parcelamento. Tais regras, no entanto, dificilmente são vistas cumpridas no dia-a-dia do mercado de consumo.

18 FILOMENO, José Geraldo Brito. Manual de direitos do consumidor. 13. ed. São Paulo: Atlas, 2015. p. 127. 
ros", e os consumidores hipervulneráveis, notadamente crianças e adolescentes, têm sido bombardeados por incentivos publicitários ao consumo ilimitado.

Não bastassem os fornecedores (empresários), o Poder Público, também, tem o condão de afetar, em determinadas situações, a liberdade de atuação e escolha do consumidor, notadamente, quando promove políticas econômicas de incentivo ao consumo. Em cenário assim, o cidadão fica, absolutamente, impotente e indefeso, como bem esclarece Antônio Carlos Efing ${ }^{19}$, "o homem não é nada para além da economia, submetendo-se a ela e às suas leis, não sendo sujeito na economia, não sendo titular de direitos, mas objeto visto que é destinatário sem estatuto dos produtos, moldados à conveniência do mercado" e acrescente-se, também, do Estado.

Apenas a título de exemplificação, nos últimos anos, diante da crise econômica que assolou o país, o Governo Brasileiro editou uma série de leis com o claro intuito de incentivar o consumo e aquecer a economia e, em determinadas situações, até mesmo provocar inegáveis distorções na liberdade de escolha dos consumidores. Assim, citam-se as leis de redução / exclusão do IPI (imposto sobre produtos industrializados), redução da taxa de juros e liberação do FGTS inativo (Fundo de Garantia sobre Tempo de Serviço) (Lei n. 13.446/2017), com o manifesto intuito de alavancar a economia. E, ainda, foi editada lei com o intuito de favorecimento do fornecedor em detrimento do consumidor, como ocorreu com a edição da recente lei que autorizou a variabilidade dos preços em virtude do instrumento de pagamento utilizado (Lei n. 13.455/2017).

A consequência dessa política econômica é, apenas, paliativa e pode trazer resultados diversos e, às vezes, indesejáveis. De fato, a injeção de dinheiro no mercado pode restabelecer a economia que se encontra estagnada, mas, por outro lado, é princípio básico da economia que o aumento na quantidade de moeda no mercado pode acarretar a inflação ${ }^{20}$, em desfavor do próprio consumidor, aumentando a discussão em torno da forma e modo de intervenção do Estado no mercado.

Tecidas tais considerações sobre o direito à educação para o consumo e a educação financeira, passa-se, agora, a analisar a sua relevância do ponto de vista da economia comportamental. Para tanto, alguns questionamentos são importantes: (a) a educação financeira influencia, eficientemente, o comportamento do consumidor no mercado de consumo? (b) de quem é a "culpa" pelo (super)endividamento do consumidor? e, (c) a educação financeira terá o condão de amenizar ou eliminar as falhas de mercado?

\section{Os POSTULADOS DA ECONOMIA COMPORTAMENTAL EM UMA COMPARAÇÃo COM A TEORIA ECONÔMICA CLÁsSICA}

A economia comportamental ou behavioral law consiste em um seguimento da Análise Econômica do Direito ou law and economics. A economia comportamental, pode-se dizer, é uma etapa mais recente de estudos da Análise Econômica do Direito, que já havia promovido intrigantes investigações jurídico-econômicas com base nos postulados da economia clássica e neoclássica. Por isso, para sua compreensão, é necessário entender, inicialmente, os postulados da teoria econômica clássica e neoclássica.

Para a Teoria Econômica Clássica, todo agente econômico (bomo economicus), incluindo, o consumidor, é racional maximizador de suas utilidades ${ }^{21}$ e retentor de uma quantidade ótima de informações em uma variedade de mercados. Em consequência disso, para a economia clássica, o indivíduo tem capacidade plena

19 EFING, Antônio Carlos. Direito do consumo e direito do consumidor: reflexões oportunas. Revista Luso-Brasileira de Direito do Consumo, Brasília, v. 1, n. 1, p. 103-120, 2011. p. 106.

20 MANKIW, Nicholas Gregory. Introdução à economia. São Paulo: Cengage Learning, 2013. p. 15.

21 Os administradores de empresas, por outro lado, são maximizadores de lucros. MANKIW, Nicholas Gregory. Introdução à economia. São Paulo: Cengage Learning, 2013. p. 453. 
para reagir a determinados incentivos (ou desincentivos) ${ }^{22}$, sempre optando pelo melhor curso de ação possível. Tudo e todos, portanto, seriam plenamente previsíveis. Em termos práticos, para a Teoria Econômica Clássica, o consumidor não é vulnerável e tem condições de decidir e escolher, livre e espontaneamente, no mercado de consumo.

Contudo, os economistas clássicos não levam em consideração, em suas percepções, que as pessoas são dotadas de imperfeições, como o fato de serem esquecidas, impulsivas, confusas, emotivas e de horizontes curtos. Tais imperfeições, de outro lado, são levadas em consideração pela psicologia e são relevantes nas tomadas de decisões dos agentes ${ }^{23}$. Isso significa que, o comportamento humano e suas decisões não são tão previsíveis assim. E é exatamente isso que a economia comportamental se debruça em estudar.

A economia comportamental, assim, decorre de estudo interdisciplinar promovido pela economia, a partir de descobertas da psicologia. Os seus primeiros precursores foram Herbert Simon, Richard Cyert, James March, Amos Tiverski e Daniel Kahneman. A partir de então, estudiosos do Direito passaram a empregá-la, tanto em análise normativa (elaboração de novas normas) quanto em análise descritiva (verificação do comportamento humano).

A economia comportamental não exsurgiu para anular a Teoria Clássica ${ }^{24}$, ao contrário, sua finalidade é modificar os elementos sem plausibilidade dessa teoria e suplementar os elementos inadequados, de modo a criar uma ferramenta com maior poder preditivo em situações específicas ${ }^{25}$.

Para a Teoria Econômica Clássica, os agentes sabem o que fazem e sempre fazem buscando o melhor para si (maximização de utilidades). Para a economia comportamental, por outro lado, o comportamento dos sujeitos não conduzirá, necessariamente, às melhores opções ${ }^{26}$. Os agentes não são absolutamente precisos na busca de suas utilidades, uma vez que maximizam sua satisfação (são satisficers) ${ }^{27}$, podendo, nesse intento, cometer erros sistemáticos por decisões imediatas e irrefletidas, notadamente, aqueles que se encontram na posição de consumidores.

Em outros termos, para os comportamentalistas, há muito mais que dados objetivos a influir entre as preferências declaradas e as escolhas efetivamente realizadas ${ }^{28}$. Manifestações neurocognitivas podem alterar, substancialmente, as escolhas dos agentes, ainda que suas preferências sejam mantidas. Enfim, estudos da economia comportamental partem do pressuposto de que, não raras são as vezes em que os agentes possuem uma racionalidade limitada, diante de uma série de vieses e heurísticas, ou seja, de erros sistemáticos provocados por atalhos cognitivos.

Amos Tiverski e Daniel Kahneman foram os economistas que deram os contornos mais atuais da economia comportamental, com base na obra intitulada Prospect Theory. Segundo seus estudos, os economistas chegaram aos seguintes postulados (erros sistemáticos): (a) as decisões estão sujeitas a uma série de distorções do julgamento (vieses) e atalhos mentais muitas vezes simplórios, que, diante de problemas complexos, apresentam respostas singelas e irrefletidas, nem sempre corretas (heurísticas); (b) diante de um quadro de

22 SANTOLIM, Cesar. Behavoral law and economics e a teoria dos contratos. In: MARQUES, Cláudia Lima; GSELL, Beate. Novas tendências do direito do consumidor. São Paulo: Revista dos Tribunais, 2015. p. 167.

23 MANKIW, Nicholas Gregory. Introdução à economia. São Paulo: Cengage Learning, 2013. p. 453.

24 Para Ivo Teixira Gico Júnior, a economia comportamental, de fato, diverge do modelo econômico tradicional em várias circunstâncias, mas essa divergência seria sistemática e não aleatória, o que significa que as características dos agentes são semelhantes, apenas é preciso adaptar os modelos para incorporar limitações cognitivas. GICO JÚNIOR, Ivo Teixeira. Introdução ao direito e economia. In: TIMM, Luciano Benetti. Direito e economia no Brasil. São Paulo: Atlas, 2012. p. 26-27.

25 SANTOLIM, Cesar. Behavoral law and economics e a teoria dos contratos. In: MARQUES, Cláudia Lima; GSELL, Beate. Novas tendências do direito do consumidor. São Paulo: Revista dos Tribunais, 2015. p. 168-169.

26 ALVES, Giovani Ribeiro Rodrigues. Economia comportamental. In: RIBEIRO, Marcia Carla Pereira; KLEIN, Vinicius. O que é análise econômica do direito: uma introdução. 2. ed. Belo Horizonte: Fórum, 2016. p. 75.

27 MANKIW, Nicholas Gregory. Introdução à economia. São Paulo: Cengage Learning, 2013. p. 454.

28 DOMINGUES, Victor Hugo. Vieses e heurísticas. In: RIBEIRO, Marcia Carla Pereira; DOMINGUES, Victor Hugo; KLEIN, Vinicius. Análise econômica do direito. Curitiba: CRV, 2016. p. 51. 
incertezas, ou de informações incompletas, as pessoas apresentam uma série de reações que não podem ser consideradas racionais; (c) as decisões dependem da forma como as questões são apresentadas (framing) e de sua disposição para assumir riscos (risk aversion), especialmente, num ambiente de incertezas; e, (d) as decisões são moldadas por uma série de fatores que bloqueiam a opção ótima²9.

Esses erros sistemáticos ocorrem, pelos estudos realizados por Daniel Kahneman ${ }^{30}$, em virtude de dois tipos de processos cognitivos (chamados de Sistemas 1 e 2, respectivamente), que fazem parte da mente humana, sendo o primeiro responsável pelas operações mentais rápidas e automáticas, sempre baseadas em associações e relacionadas à intuição e, o segundo, é mais controlado, vagaroso, flexível, autogovernado, associado ao raciocínio, representações e tempo.

Uma das principais funções do Sistema 2 é a de monitorar e controlar os pensamentos, bem como as ações automáticas "sugeridos” do Sistema $1^{31}$. Quando o consumidor é exposto a ilusões, alucinações, pressões de grupo e paixões, é o Sistema 2 o encarregado de corrigir essas soluções falaciosas, o que nem sempre acontece, acarretando os erros e desvios nas tomadas de decisões. É preciso, portanto, levar em consideração toda a questão emocional envolvida no funcionamento mental nas tomadas de decisões, pois todo estímulo tem uma avaliação afetiva que não é consciente ${ }^{32}$.

A partir dessas constatações e postulados, no próximo tópico, serão apresentadas algumas heurísticas de julgamento que podem exemplificar e comprovar a teoria em estudo. Posteriormente, após a análise dessas distorções neurocognitivas, avaliar-se-á de que modo a educação formal para o consumo pode eliminar ou amenizar os erros sistemáticos.

\section{HeURísticas e Vieses: as distorções neUROCognitivas nas tomadas de deCisões dos CONSUMIDORES}

Heurísticas e vieses são pensamentos que vêm à mente rapidamente e sem muita reflexão ${ }^{33}$. São decisões popularmente conhecidas como "bate-pronto". Trata-se, enfim, de uma simplificação no processo decisório do agente que pode levá-lo a decisões adequadas e imperfeitas. Apesar disso, não se pode condená-los totalmente no dia a dia das relações de mercado, especialmente as relações de consumo, haja vista que o mercado é dinâmico e necessita de decisões rápidas, mesmo diante de situações com grande quantidade de dados e variáveis.

Muitas das heurísticas e vieses (manifestações neurocognitivas) podem ser estimuladas ou evitadas de acordo com os incentivos aos quais as pessoas são expostas ${ }^{34}$. Isto quer dizer que práticas comerciais e políticas econômicas podem influir nas decisões dos consumidores, nos diversos mercados de consumo. Aliás, isso é inerente ao mercado de consumo, já que consumidor e fornecedor possuem comportamentos distintos, mas complementares. Se, de um lado, o consumidor tem necessidades de bens e serviços para a sua subsistência, bem-estar e comodidade, de outro lado, o fornecedor precisa vender tais bens e serviços. Assim, enquanto o fornecedor visa ao lucro, o consumidor visa ao bem-estar (satisfação e comodidade); enquanto os fornecedores aspiram custos momentâneos e benefícios futuros, os consumidores aspiram

29 DOMINGUES, Victor Hugo. Vieses e heurísticas. In: RIBEIRO, Marcia Carla Pereira; DOMINGUES, Victor Hugo; KLEIN, Vinicius. Análise econômica do direito. Curitiba: CRV, 2016. p. 51-52.

30 KAHNEMAN, Daniel. Rápido e devagar: duas formas de pensar. Rio de Janeiro: Objetiva, 2012. p. 58.

31 KAHNEMAN, Daniel. Rápido e devagar: duas formas de pensar. Rio de Janeiro: Objetiva, 2012. p. 58.

32 OLIVEIRA, Amanda Flávio de; CARVALHO, Diógenes Faria de. Vulnerabilidade comportamental do consumidor: por que é preciso proteger o consumidor superendividado. Revista de Direito do Consumidor, São Paulo, v. 104, mar./abr. 2016. p. 185.

33 KAHNEMAN, Daniel. Rápido e devagar: duas formas de pensar. Rio de Janeiro: Objetiva, 2012. p. 156.

34 DOMINGUES, Victor Hugo. Vieses e heurísticas. In: RIBEIRO, Marcia Carla Pereira; DOMINGUES, Victor Hugo; KLEIN, Vinicius. Análise econômica do direito. Curitiba: CRV, 2016. p. 52. 
benefícios momentâneos e custos futuros (desconto hiperbólico).

O chamado desconto hiperbólico, provavelmente, representa uma das descobertas mais plausíveis da economia comportamental e revela um problema de autocontrole. Segundo essa descoberta, as pessoas sofrem conflitos entre as alternativas de longo e curto prazo e que podem resultar em escolhas totalmente inconsistentes. É o dilema que o consumidor se depara, quando se pretende adquirir um produto de valor considerável em uma determinada loja: (a) comprar em curto prazo e sair imediatamente com a mercadoria ou, (b) poupar em longo prazo e adquirir a mercadoria no futuro ${ }^{35}$.

Gregory Mankiw ${ }^{36}$ exemplifica a situação da seguinte forma: imagine as seguintes opções, em que uma determinada pessoa é submetida a decidir: (a) passar 50 minutos cumprindo uma tarefa irritante imediatamente ou passar 60 minutos cumprindo a tarefa irritante amanhã? A maioria das pessoas preferem a segunda opção; (b) passar 50 minutos cumprindo a tarefa irritante daqui a 90 dias ou passar 60 minutos cumprindo a tarefa irritante daqui a 91 dias? A maioria das pessoas preferem a primeira opção.

Quando olham para o futuro, as pessoas minimizam a quantidade de tempo dedicada à tarefa. Mas, diante da perspectiva de cumprir imediatamente, as pessoas preferem adiar. Os economistas acreditam que a decisão consumo-poupança é um exemplo importante dessa inconsistência ao longo do tempo. Para muitas pessoas, os gastos (consumo) representam uma forma de satisfação imediata. Por outro lado, poupar (poupança) exige um sacrifício do presente em troca de uma recompensa futura ${ }^{37}$.

Dessa distorção cognitiva decorrem os chamados consumidores míopes, ou seja, que enxergam apenas de perto e possuem uma visão embaçada no longo alcance. Essa constatação da economia comportamental explica, de maneira bastante convincente e plausível, as decisões dos consumidores por compras a prazo ou por aquisição de créditos bancários, acarretando o comprometimento das suas rendas e resultando nos endividamentos frequentes.

O viés do desconto hiperbólico é, ainda, exacerbado por outro viés reconhecido pela economia comportamental, qual seja, o do otimismo. A ocorrência desse viés torna o agente (consumidor) acomodado, impedindo-o de agir preventivamente, pois ele acredita que "o pior" não vai acontecer, ou que são muito maiores as probabilidades de uma situação desagradável acontecer aos outros e não a ele mesmo ${ }^{38}$.

O viés do otimismo é nitidamente verificado na realidade do dia a dia, em que os consumidores, de forma precipitada, aumentam mais e mais seus gastos, com a convicção otimista de que "as coisas irão melhorar"39, "vamos conseguir pagar", "não vamos passar por dificuldades".

Outra modalidade de heurística que pode influir no julgamento dos agentes é a chamada heurística de disponibilidade. Essa manifestação neurocognitiva explica que os agentes tendem a adotar as informações que lhe vêm mais instantaneamente à mente, seja por que são mais recentes, seja porque são marcantes. Assim, os agentes avaliam e tomam suas decisões de acordo com eventos anteriores, que são hiperestimados ou subestimados, de acordo com o momento ou a importância em que ocorreram.

A heurística da disponibilidade mostra que, se um consumidor se informou sobre um dado evento negativo ou positivo, recentemente, essa pessoa tende a superestimar a probabilidade da ocorrência desse evento, tal como um acidente violento, cuja mensagem forma uma base disponível e pronta para superestimar o risco de similar incidente no futuro ${ }^{40}$.

35 OLIVEIRA, Amanda Flávio de; CARVALHO, Diógenes Faria de. Vulnerabilidade comportamental do consumidor: por que é preciso proteger o consumidor superendividado. Revista de Direito do Consumidor, São Paulo, v. 104, p. 181-201, mar./abr. 2016. p. 185.

36 MANKIW, Nicholas Gregory. Introdução à economia. São Paulo: Cengage Learning, 2013. p. 456-457.

37 MANKIW, Nicholas Gregory. Introdução à economia. São Paulo: Cengage Learning, 2013. p. 458.

38 FORGIONI, Paula A. Contratos empresariais: teoria geral e aplicação. 2. ed. São Paulo: Revista dos Tribunais, 2016. p. 102.

39 OLIVEIRA, Amanda Flávio de; CARVALHO, Diógenes Faria de. Vulnerabilidade comportamental do consumidor: por que é preciso proteger o consumidor superendividado. Revista de Direito do Consumidor, São Paulo, v. 104, p. 181-201, mar./abr. 2016 . p. 187.

40 OLIVEIRA, Amanda Flávio de; CARVALHO, Diógenes Faria de. Vulnerabilidade comportamental do consumidor: por que é 
Da mesma forma, pode ocorrer o inverso, quando a ocorrência do evento não é frequente ou é distante, provocando a subestimação de sua nova ocorrência na vida do consumidor.

$\mathrm{Na}$ relação consumerista, isso pode ocorrer com as chamadas publicidades dissimuladas em forma de reportagem jornalística ${ }^{41}$. Por exemplo, uma fornecedora de produtos lácteos pode divulgar uma publicidade com a seguinte informação: "o iogurte é fundamental para a prevenção ao câncer". Diante dessa publicidade, os consumidores podem superestimar o consumo do iogurte, como forma de prevenir a doença ${ }^{42}$.

A heurística de ancoragem, para citar outra modalidade de manifestação neurocognitiva, revela que, em julgamentos sob incerteza, quando as pessoas devem realizar estimativas ou decidir sobre alguma quantia, elas tendem a ajustar a sua resposta com base em algum valor inicial disponível que servirá como âncora ${ }^{43}$. Trata-se, assim, de uma espécie de sugestão que o consumidor acaba tomando por base para tomar suas decisões ${ }^{44}$.

Kahneman expõe uma situação bastante elucidativa acerca da heurística de ancoragem. Afirma que, certa vez, o supermercado Sioux City, localizado em Iowa, ofertou uma promoção 10\% (dez por cento) abaixo do preço normal para a sopa da marca Campbell's. A promoção foi anunciada de duas formas. Na primeira, o produto foi anunciado com limite quantitativo de aquisição de 12 (doze) unidades, por pessoa. Na segunda, o produto foi anunciado sem limites quantitativos de aquisição. Por meio desse exemplo, verifica-se, perfeitamente, o efeito da ancoragem na mente dos consumidores. Enquanto na primeira oferta os consumidores adquiriram, em média, 7 (sete) unidades do produto, na segunda, os consumidores adquiriram, apenas, 3 (três) ${ }^{45}$.

A heurística em questão pode explicar mecanismos de indução ao consumo ou indução ao consumo em maior escala a partir de ofertas e publicidades agressivas ou direcionadas e que pode contribuir para o superendividamento do consumidor ${ }^{46}$.

Por último, a heurística de representatividade, nos ensinamentos de Russel Korobkin e Thomas Ulen ${ }^{47}$, refere-se à tendência dos sujeitos de superestimar a correlação entre o que algum objeto aparenta ser e o que esse objeto realmente é. Essa heurística leva o consumidor a considerar as semelhanças entre dois objetos (ou eventos) para inferir que um deles possui as características de outro ao qual ele se assemelha. Em simples palavras, trata-se de generalizar, em uma categoria mais ampla, os objetos de comparação, tomando-se por base as experiências anteriores.

No campo das relações de consumo, a heurística de representatividade pode ser verificada no desempenho de determinado produto no passado ou presente ser representativo de um desempenho geral que o produto continuará a ter no futuro. É o que ocorre com determinados produtos de marcas famosas que representam, na mente do consumidor, sempre um bom desempenho, como é o caso, do sabão em pó da cor azul escuro.

preciso proteger o consumidor superendividado. Revista de Direito do Consumidor, São Paulo, v. 104, p. 181-201, mar./abr. 2016. p. 187. 41 A publicidade dissimulada é proibida pelo Conar, no art. 30, que estabelece: "A peça jornalística sob a forma de reportagem, artigo, nota, texto-legenda ou qualquer outra que se veicule mediante pagamento, deve ser apropriadamente identificada para que se distinga das matérias editoriais e não confunda o consumidor".

42 O art. 36 do Código do Consumidor adota a regra da obrigatória identificação da publicidade, por meio do qual o consumidor deve ter consciência inequívoca de que é o destinatário de uma publicidade. E, com base nesse fundamento legal, é que se proíbe as publicidades que sejam dissimuladas, clandestinas e subliminares e que têm o condão de distorcer a racionalidade do consumidor.

43 SANTOLIM, Cesar. Behavoral law and economics e a teoria dos contratos. In: MARQUES, Cláudia Lima; GSELL, Beate. Novas tendências do direito do consumidor. São Paulo: Revista dos Tribunais, 2015. p. 170.

44 KAHNEMAN, Daniel. Rápido e devagar: duas formas de pensar. Rio de Janeiro: Objetiva, 2012. p. 156.

45 KAHNEMAN, Daniel. Rápido e devagar: duas formas de pensar. Rio de Janeiro: Objetiva, 2012. p. 161.

46 OLIVEIRA, Amanda Flávio de; CARVALHO, Diógenes Faria de. Vulnerabilidade comportamental do consumidor: por que é preciso proteger o consumidor superendividado. Revista de Direito do Consumidor, São Paulo, v. 104, p. 181-201, mar./abr. 2016. p. 188. 47 KOROBKIN; ULEN apud OLIVEIRA, Amanda Flávio de; FERREIRA, Felipe Moreira dos Santos. Análise econômica do direito do consumidor em períodos de recessão: uma abordagem a partir da economia comportamental. Revista de Direito do Consumidor, São Paulo, v. 81, p. 13-38, jan./mar. 2012. p. 23. 
Enfim, essas heurísticas e vieses estão presentes na vida das pessoas quando se faz escolhas e, o Direito, por missão institucional e vocação temática, é o campo da ciência que pode moldar com eficiência o design dos incentivos ${ }^{48}$. A alternativa que o presente artigo se propõe a averiguar diz respeito à educação formal e inicial do consumidor, como forma de potencializar a reflexão e a crítica do consumidor. É o que se passa a analisar com base no próximo tópico.

\section{A EDUCAÇão Formal E INICIAL PARA O CONSUMO PELA Ótica da ECONOMIA COMPORTAMENTAL GARANTE A PRESENÇA REFLETIDA DO CONSUMIDOR NO MERCADO?}

Muito se discute acerca da educação formal destinada ao consumidor, como forma de preveni-lo e de orientá-lo a uma presença mais refletida no mercado de consumo, evitando, assim, as armadilhas decorrentes das práticas comerciais e, mesmo, da política econômica, os quais, frequentemente, acarretam o consumismo e, consequentemente, o endividamento do consumidor.

Mas de quem é, efetivamente, a "culpa" pelo endividamento ou superendividamento do consumidor? Seria do próprio consumidor que anseia pelo seu bem-estar e comodismo, fazendo gastos desnecessários e supérfluos ou seria dos fornecedores, notadamente, os de crédito, que adotam práticas comerciais agressivas e exploradoras da irracionalidade do consumidor e não avaliam corretamente o perfil do seu beneficiário?

A discussão é profunda e parece entrar em um círculo vicioso: ora, é o consumidor que não reflete sobre seus atos de consumo, ora, é o fornecedor o responsável por distorcer o comportamento do consumidor.

Um fato, no entanto, é certo. Economistas, psicólogos e juristas concordam que o consumidor se encontra em situação de inferioridade frente ao fornecedor, no mercado de consumo. No entanto, enquanto os juristas nominam esse fato como vulnerabilidade, os economistas o nominam de racionalidade limitada. Essa limitação da racionalidade, na esfera econômica, decorre da assimetria de informações, ao passo que a vulnerabilidade, na esfera jurídica, decorre do reconhecimento da presunção de inferioridade técnica, econômica, fática e jurídica do consumidor. São, portanto, dois conceitos muito aproximados. Em verdade, a perspectiva da racionalidade limitada (elemento econômico) é mais um fundamento para a compreensão da vulnerabilidade (elemento jurídico).

O reconhecimento dessa inferioridade do consumidor é importante para a percepção, também, da necessidade de intervenção do Estado na relação e no mercado de consumo. E é, nesse tema, que se diferenciam as abordagens clássica e behaviorista. Consoante Cesar Santolin"4, "a behavioral, ao prestigiar as limitações da racionalidade acaba por enfatizar não somente a conveniência mas até a necessidade de um maior dirigismo contratual, abrindo portas para soluções que a abordagem neoclássica qualifica como paternalista".

$\mathrm{Na}$ concepção dos comportamentalistas, portanto, a intervenção do Estado na relação e no mercado de consumo é necessária, mesmo porque o mercado de consumo deve ser harmônico e equilibrado ${ }^{50}$, para proteger não apenas a pessoa do consumidor, mas também a saúde do próprio mercado de consumo. Mas, como deve ser feita essa intervenção? Qual a política pública a ser adotada para assegurar a harmonia das relações e do mercado de consumo? Uma das alternativas propostas por este artigo é a educação formal e

48 DOMINGUES, Victor Hugo. Vieses e heurísticas. In: RIBEIRO, Marcia Carla Pereira; DOMINGUES, Victor Hugo; KLEIN, Vinicius. Análise econômica do direito. Curitiba: CRV, 2016. p. 52.

49 SANTOLIM, Cesar. Behavoral law and economics e a teoria dos contratos. In: MARQUES, Cláudia Lima; GSELL, Beate. Novas tendências do direito do consumidor. São Paulo: Revista dos Tribunais, 2015. p. 176.

50 O inciso II do art. $4^{\circ}$ do Código do Consumidor assegura o princípio da harmonização, como princípio da Política Nacional das Relações de Consumo, ao prescrever: "harmonização dos interesses dos participantes das relações de consumo e compatibilização da proteção do consumidor com a necessidade de desenvolvimento econômico e tecnológico, de modo a viabilizar os princípios nos quais se funda a ordem econômica (art. 170, da Constituição Federal), sempre com base na boa-fé e equilíbrio nas relações entre consumidores e fornecedores". 
inicial dos consumidores, ainda jovens, como forma de preparar os seus comportamentos para o mercado de consumo.

Diante dessas primeiras impressões, há uma aparente condução a que conclua, a partir da economia comportamental, pela necessidade da educação formal e inicial do consumidor. Mas será essa política pública, de fato, efetiva e eficiente para proteger o consumidor frente às estratégias do fornecedor?

Apesar de reconhecer a necessidade da intervenção estatal, parece que a economia comportamental não vê, na educação formal e inicial, a chave para solucionar desequilíbrios e oportunismos do mercado de consumo. Evidentemente, não se pode negar que informação e educação nunca são de menor relevância, sendo indiscutivelmente importante para amenizar as discrepâncias do mercado.

A educação formal para o consumo é importante na medida em que está diretamente relacionada ao exercício típico da cidadania, sendo ato inerente à vida de todos os cidadãos. Tanto isso o é verdade que, o Presidente norte-americano, John Fitzgerald Kennedy, já em 1962, encaminhou Mensagem Especial ao Congresso dos Estados Unidos, com os seguintes dizeres:

Consumidores, por definição, somos todos nós. Os consumidores são o maior grupo econômico na economia, afetando e sendo afetado por quase todas as decisões econômicas, públicas e privadas [...]. Mas são o único grupo importante da economia não eficazmente organizado e cujos posicionamentos quase nunca são ouvidos ${ }^{51}$.

Entretanto, o mercado, sempre, é dinâmico. Os fornecedores, sempre, maximizarão seus lucros, buscando mecanismos (e armadilhas) diversos para chamar a atenção do consumidor. E os consumidores sempre maximizarão seu bem-estar, no sentido de satisfazer as suas diversas necessidades e comodismos, destinando seus rendimentos para o consumismo, o que, aliás, faz parte da economia capitalista, como explicam Amanda Flavio de Oliveira e Rute Saraiva ${ }^{52}$ : "se o capitalismo está escolhido e consagrado como modelo econômico, a ação dos agentes econômicos privados é, portanto, legítima".

Outrossim, segundo Oren Bar-Grill, em certos mercados, os erros dos consumidores e as estratégias dos fornecedores como resposta a esses erros são responsáveis por perdas substanciais de bem-estar, ou seja, os fornecedores são e sempre serão oportunistas e se aproveitarão da condição de inferioridade do consumidor para atingir o seu intento (o lucro). O consumidor, por outro lado, não é uma máquina com capacidade computacional ilimitada e em um ambiente ceteris paribus ${ }^{53}$, estando, pois, submetidos às estratégias do fornecedor.

Por conseguinte, é de se destacar, ainda, que as heurísticas e vieses são regras gerais de influência ${ }^{54}$ do comportamento que afetam o psicológico e o inconsciente do ser humano. Ao agirem dessa forma, as heurísticas e vieses tornam-se invencíveis, mesmo diante de ostensiva informação e educação, ou, como diz Daniel Kahneman ${ }^{55}$, "os insights cognitivos e as heurísticas são mais poderosos que a informação".

Aliás, a adoção da educação formal e inicial para o consumo, no ensino básico ${ }^{56}$, contraria postulados

51 KENNEDY, 1962 apud CAVALIERI FILHO, Sergio. Programa de direito do consumidor. 4. ed. São Paulo: Atlas, 2014. p. 101-102. 52 OLIVEIRA, Amanda Flávio de; SARAIVA, Rute. O Tribunal de Justiça de São Paulo e a anulação de multa aplicada à McDonald's em razão de publicidade abusiva: ou, a quem cabe educar as nossas crianças? Revista de Direito do Consumidor, São Paulo, v. 106, p. 325-355, jul./ago. 2016. p. 327.

53 OLIVEIRA, Amanda Flávio de; SARAIVA, Rute. O Tribunal de Justiça de São Paulo e a anulação de multa aplicada à McDonald's em razão de publicidade abusiva: ou, a quem cabe educar as nossas crianças? Revista de Direito do Consumidor, São Paulo, v. 106, p. 325-355, jul./ago. 2016. p. 338.

54 SANTOLIM, Cesar. Behavoral law and economics e a teoria dos contratos. In: MARQUES, Cláudia Lima; GSELL, Beate. Novas tendências do direito do consumidor. São Paulo: Revista dos Tribunais, 2015. p. 170.

55 KAHNEMAN, Daniel. Rápido e devagar: duas formas de pensar. Rio de Janeiro: Objetiva, 2012. p. 156.

56 O Sistema Educacional Brasileiro é constituído por dois níveis [art. 21 da Lei n. 9.394/1996 (Lei de Diretrizes e Bases da Educação)]: (a) Educação básica; e, (b) Educação superior. O primeiro nível, por sua vez, é composto por três etapas: (a) educação infantil (crianças de até 6 (seis) anos de idade); (b) ensino fundamental (crianças e adolescentes dos 7 (sete) até os 15 (quinze) anos); e, (c) ensino médio (adolescentes de 16 (dezesseis) a 18 (dezoito) anos). 
da própria economia comportamental, notadamente, a heurística de disponibilidade, já que a criança e o adolescente, por ocasião do momento em que recebem a educação, ainda não são efetivos consumidores, no sentido de ser participantes da relação de consumo como compradores e adquirentes, o que somente vem a ocorrer na fase adulta, quando o aprendizado já se tornou informação distante, provocando no agente uma subestimação dos ensinamentos transmitidos.

No mesmo sentido, Bruna Giacomini Lima e Vitor Hugo do Amaral Ferreira ${ }^{57}$ dissertam que a simples educação passiva, teórica e abstrata não encontra equivalência nas poderosas forças psicológicas. A educação e a informação são certamente valiosas, entretanto, é precioso reconhecer-se a limitação dessas iniciativas e valer-se de instrumentos adicionais de tutela.

A pesquisa, portanto, não desconsidera a elaboração de eventual política pública, no âmbito da educação formal para o consumo. Mas, uma ação governamental para a educação do consumidor seria, apenas, um reforço, um complemento, destinado a atuar, significativamente, na mudança de mentalidade e comportamento do cidadão. Este, que está, no mercado de consumo, sujeito a práticas comerciais que distorcem a sua racionalidade e por políticas econômicas que, apesar de lhe proporcionar o bem-estar, também o incentiva ao consumo, causando-lhe drásticas consequências sociais e financeiras, como o endividamento e a escassez de recursos naturais.

Pensa-se como Esptein ${ }^{58}$, que as manifestações neurocognitivas (heurísticas e vieses) conduzem à conclusão de que a melhor forma de aprendizagem para o consumidor é a partir dos erros cometidos no passado. Trata-se do conhecimento obtido pela experiência. E, nesse particular, a educação para o consumo deve partir e contar com a participação da família, a qual tem o primordial dever de educar as suas crianças e jovens, em corresponsabilidade com a sociedade e o Estado, como preconiza o art. $227^{59}$ da Constituição da República.

Ainda que nem todas as famílias tenham familiaridade com as heurísticas e vieses do mercado de consumo, é pela educação transmitida pela família que o futuro consumidor toma conhecimento dos erros sistemáticos cometidos em compras desnecessárias, dos problemas patrimoniais decorrentes do endividamento e do superenvididamento, do tamanho do poder aquisitivo da família, das prioridades familiares na aquisição de produtos e na contratação de serviços, da conscientização acerca do desperdício de alimentos e, especialmente, do equilíbrio entre receitas e despesas.

\section{Considerações finais}

Economistas, psicólogos e juristas concordam que o consumidor se encontra em situação de inferioridade frente ao fornecedor no mercado de consumo. No entanto, enquanto os juristas nominam esse fato como vulnerabilidade, os economistas o nominam de racionalidade limitada. O reconhecimento dessa inferioridade do consumidor é importante para que se analise o papel de intervenção do Estado na relação e no mercado de consumo, fato este não reconhecido pelos economistas clássicos em razão de seu caráter paternalista.

57 LIMA, Bruna Giacomini; FERREIRA, Vitor Hugo do Amaral. Homo economicus: os (des)encontros da sociedade de consumo superendividada. In: FERREIRA, Vitor Hugo do Amaral; CARVALHO, Diógenes Faria de; SANTOS, Nivaldo dos. Sociedade de consumo: pesquisas em direito do consumidor. Goiânia: Espaço Acadêmico, 2015. p. 64.

58 ESPTEIN apud SANTOLIM, Cesar. Behavoral law and economics e a teoria dos contratos. In: MARQUES, Cláudia Lima; GSELL, Beate. Novas tendências do direito do consumidor. São Paulo: Revista dos Tribunais, 2015. p. 178.

59 Art. 227. É dever da família, da sociedade e do Estado assegurar à criança, ao adolescente e ao jovem, com absoluta prioridade, o direito à vida, à saúde, à alimentação, à educação, ao lazer, à profissionalização, à cultura, à dignidade, ao respeito, à liberdade e à convivência familiar e comunitária, além de colocá-los a salvo de toda forma de negligência, discriminação, exploração, violência, crueldade e opressão. BRASIL. Constituição (1988). Constituição da República Federativa do Brasil. Disponível em: <http://www.planalto.gov.br/ccivil_03/constituicao/constituicao.htm>. Acesso em: 5 maio 2018. 
Práticas comerciais do mercado de consumo e algumas políticas econômicas adotadas pelo governo conduzem o agente ao ato de consumo. Tais fatos, no entanto, são totalmente legítimos. É evidente que o empresário que atua no mercado com o objetivo exclusivo de lucro deverá envidar todos os seus esforços para a comercialização de seus produtos e serviços, disponibilizando, para tanto, ofertas e publicidades direcionadas a angariar clientes consumidores. Da mesma forma, o Estado brasileiro que é, por opção, capitalista, tende à adoção de políticas econômicas voltadas ao crescimento e desenvolvimento econômicos.

A educação formal para o consumo, do ponto de vista da economia comportamental, pode não ser suficiente para corrigir ou amenizar as distorções neurocognitivas (heurísticas e vieses) que afetam o consumidor. Isso porque o mercado não é perfeito e estático e o consumidor não é um biônico e nem um maximizador racional, de modo que tais distorções neurocognitivas tornam-se invencíveis, mesmo diante de ostensiva informação e educação.

A melhor forma de aprendizagem para o consumidor, portanto, começa com os erros cometidos no passado (experiência). E, nesse particular, a educação para o consumo deve partir e contar com a participação da família, em corresponsabilidade com a sociedade e o Estado, pois é nesse ambiente que a criança e o jovem consumidor tende a receber o aprendizado mais efetivo e eficiente, baseado em experiências normalmente já vivenciadas e capazes de lhe proporcionar a captação de uma racionalidade mais adequada.

Por último, não se corrobora o entendimento de que o fornecedor não deva ser tomado como o principal responsável pela promoção da educação do consumidor, não por causa do conflito de interesses, mas sim porque, economicamente, esse dever de educação geraria maiores custos de transação ao fornecedor, acarretando a transferência desses custos para o próprio mercado de consumo.

\section{REFERÊNCIAS}

ALVES, Giovani Ribeiro Rodrigues. Economia comportamental. In: RIBEIRO, Marcia Carla Pereira; KLEIN, Vinicius. O que é análise econômica do direito: uma introdução. 2. ed. Belo Horizonte: Fórum, 2016. p. 75-82.

ASSOCIAÇÃO DE EDUCAÇÃO FINANCEIRA DO BRASIL. Educação financeira nas Escolas. Disponível em: <http://www.aefbrasil.org.br/index.php/programas-e-projetos/educacao-financeira-nas-escolas/>. Acesso em: 6 fev. 2018.

CAVALIERI FILHO, Sergio. Programa de direito do consumidor. 4. ed. São Paulo: Atlas, 2014.

COURI, Sergio. Liberalismo e societalismo. Brasília: UnB, 2001.

DOMINGUES, Victor Hugo. Vieses e heurísticas. In: RIBEIRO, Marcia Carla Pereira; DOMINGUES, Victor Hugo; KLEIN, Vinicius. Análise econômica do direito: justiça e desenvolvimento. Curitiba: CRV, 2016. p. 49-53.

EFING, Antônio Carlos. Direito do consumo e direito do consumidor: reflexões oportunas. Revista LusoBrasileira de Direito do Consumo, Brasília, v. 1, n. 1, p. 103-120, 2011.

EFING, Antônio Carlos; POLEWKA, Gabriele; OYAGUE, Olenka Woolcott. A crise econômica brasileira e o superendividamento da população: emergência do aprimoramento legislativo para a tutela social. Revista de Direito do Consumidor, São Paulo, v. 24, n. 101, set./out. 2015.

FILOMENO, José Geraldo Brito. Manual de direitos do consumidor. 13. ed. São Paulo: Atlas, 2015.

FORGIONI, Paula A. Contratos empresariais: teoria geral e aplicação. 2. ed. São Paulo: Revista dos Tribunais, 2016. 
GICO JUNIOR, Ivo Teixeira. Introdução ao direito e economia. In: TIMM, Luciano Benetti. Direito e economia no Brasil. São Paulo: Atlas, 2012. p. 1-33.

GRUNDMANN, Stefan. A proteção funcional do consumidor: novos modelos de consumidor à luz de teorias recentes. In: MARQUES, Cláudia Lima; GSELL, Beate. Novas tendências do direito do consumidor. São Paulo: Revista dos Tribunais, 2015. p. 23-45.

KAHNEMAN, Daniel. Rápido e devagar: duas formas de pensar. Rio de Janeiro: Objetiva, 2012.

LIMA, Bruna Giacomini; FERREIRA, Vitor Hugo do Amaral. Homo economicus: os (des)encontros da sociedade de consumo superendividada. In: FERREIRA, Vitor Hugo do Amaral; CARVALHO, Diógenes Faria de; SANTOS, Nivaldo dos. Sociedade de consumo: pesquisas em direito do consumidor. Goiânia: Espaço Acadêmico, 2015. p. 52-72.

MANKIW, Nicholas Gregory. Introdução à economia. São Paulo: Cengage Learning, 2013.

MARQUES, Cláudia Lima. Manual de direito do consumidor. 6. ed. São Paulo: Revista dos Tribunais, 2014.

MORAIS, Ezequiel; PODESTÁ, Fábio Henrique; CARAZAI, Marcos Marins. Código de Defesa do Consumidor comentado. São Paulo: Revista dos Tribunais, 2010.

MUÑOZ, Maria Paula Costa Bertran. Paralelismo entre assimetria de informações e vulnerabilidade dos consumidores: uma análise acerca de juros em contratos de concessão de crédito. Revista de Direito do Consumidor, São Paulo, v. 86, p. 47-63, mar./abr. 2013.

OLIVEIRA, Amanda Flávio de; CARVALHO, Diógenes Faria de. Vulnerabilidade comportamental do consumidor: por que é preciso proteger o consumidor superendividado. Revista de Direito do Consumidor, São Paulo, v. 104, p. 181-201, mar./abr. 2016.

OLIVEIRA, Amanda Flávio de; FERREIRA, Felipe Moreira dos Santos. Análise econômica do direito do consumidor em períodos de recessão: uma abordagem a partir da economia comportamental. Revista de Direito do Consumidor, São Paulo, v. 81, p. 13-38, jan./mar. 2012.

OLIVEIRA, Amanda Flávio de; SARAIVA, Rute. O Tribunal de Justiça de São Paulo e a anulação de multa aplicada à McDonald's em razão de publicidade abusiva: ou, a quem cabe educar as nossas crianças? Revista de Direito do Consumidor, São Paulo, v. 106, p. 325-355, jul./ago. 2016.

RIBEIRO, Marcia Carla Pereira. Racionalidade limitada. In: RIBEIRO, Marcia Carla Pereira; KLEIN, Vinicius. O que é análise econômica do direito: uma introdução. 2. ed. Belo Horizonte: Fórum, 2016. p. 59-65.

RIBEIRO, Marcia Carla Pereira; GALESKI JUNIOR, Irineu. Teoria geral dos contratos: contratos empresariais e análise econômica. 2. ed. São Paulo: Revista dos Tribunais, 2015.

RIBEIRO, Marcia Carla Pereira; MARTINEZ, Sergio Rodrigo. A ética econômica no ensino do direito ambiental segundo a perspectiva de Amartya Sen. In: RIBEIRO, Marcia Carla Pereira; MARTINEZ, Sergio Rodrigo. Desenvolvimento e meio ambiente: o pensamento econômico de Amartya Sen. Belo Horizonte: Fórum, 2011. p. 129-147.

SANTOLIM, Cesar. Behavoral law and economics e a teoria dos contratos. In: MARQUES, Cláudia Lima; GSELL, Beate. Novas tendências do direito do consumidor. São Paulo: Revista dos Tribunais, 2015. p. 166-181.

TARTUCE, Flavio; NEVES, Daniel Amorim Assumpção. Manual de direito do consumidor: direito material e processual. 2. ed. São Paulo: Método, 2013.

VERÇOSA, Haroldo Malheiros Duclerc. Direito comercial: teoria geral do contrato. 2. ed. São Paulo: Revista dos Tribunais, 2014.

WILLIAMSON, Oliver. The mecanisms of governance. New York: Oxford University Press, 1996. 
Para publicar na revista Brasileira de Políticas Públicas, acesse o endereço eletrônico www.rbpp.uniceub.br

Observe as normas de publicação, para facilitar e agilizar o trabalho de edição. 